\title{
MOTIVASI DAN PERHATIAN SISWA SERTA PENGARUHNYA TERHADAP HASIL PEMBELAJARAN PAI DI SEKOLAH MENENGAH PERTAMA
}

\author{
Yeddawati $^{1}$, Ahmad Lahmi ${ }^{2}$, Syaflin Halim ${ }^{3}$ \\ ${ }^{1}$ Program Pascasarjana, Universitas Muhammadiyah Sumatera Barat \\ ${ }^{2,3}$ Fakultas Agama Islam, Universitas Muhammadiyah Sumatera Barat \\ Email: yeddawati@gmail.com
}

\begin{abstract}
The purpose of this study is to know the description of students' attention and motivation and their influence on pai learning outcomes at Public Junior High School 1 Sungai Beremes, West Pasaman Regency. This research is descriptive and quantitative through sample withdrawal based on statistical analysis. The data in this study was obtained by distributing questionnaires to 8th graders with a sample count of 56. This study stated that: 1). The results of studying Islamic religious education are in a high category with an average score of 80.72 which is highly motivated (120.09\%) and attention is also high (86.53\%), 2). The effect of siginifkan and positive on learning motivation on PAI learning outcomes is $0.3 \%$ with $99.7 \%$ influenced by other variables. 3). There is a significant and positive influence on PAI students which is $0.2 \%$ with $99.8 \%$ due to other factors, and 4). There was a significant and positive influence between the learning motivation and the attention of the students who simultaneously on pai learning results with the results of Fhitung (Ftabel (0.136 > 3.16)then the percentage of influence was $0.005 \%$ and $0.5 \%$ influenced by other variables.
\end{abstract}

Keywords: Learning Motivation, Attention, Learning Outcomes

\begin{abstract}
Abstrak
Tujuan penelitian ini mengetahui deskripsi perhatian dan motivasi siswa serta pengaruhnya terhadap hasil pembelajaran PAI di Sekolah Menengah Pertama Negeri 1 Sungai Beremes, Kabupaten Pasaman Barat. Penelitian ini bersifat deskriptif dan kuantitatif melalui penarikan sampel berdasarkan analisis statistik. Data pada penelitian ini diperoleh dengan menyebarkan kuesioner kepada siswa kelas 8 dengan jumlah sampel sebanyak 56. Penelitian ini menyatakan bahwa: 1). Hasil belajar pendidikan agama Islam berada pada kategori tinggi dengan nilai rerata sebesar 80.72 yang diikiti dengan motivasi yang tinggi (120.09\%) dan perhatian yang juga tinggi (86.53\%), 2). Adanya pengaruh siginifkan dan positif pada motivasi belajar terhadap hasil belajar PAI yaitu sebesar $0.3 \%$ dengan $99.7 \%$ nya dipengaruhi oleh variabel lain. 3). Adanya pengaruh signifikan dan positif terhadap peserta didik PAI iaitu sebesar 0.2\% dengan 99.8\% nya disebabkan factor lain, dan 4). Adanya pengaruh signifikan dan positif antara motivasi belajar serta perhatian peserta didik yang secara bersamaan terhadap hasil belajar PAI dengan hasil hasil $F_{\text {hitung }}<F_{\text {tabel }}(0,136>3,16)$ maka persentase pengaruhnya 0,005\% dan 0,5\% dipengaruhi oleh variabel lain.

Kata Kunci: Motivasi Belajar, Perhatian, Hasil Belajar
\end{abstract}




\section{PENDAHULUAN}

Penyelenggaraan pendidikan agama Islam pada setiap jenjang pendidikan merupakan bagian dari implementasi Undang-undang republik Indonesia. Oleh karenanya jenjang pendidikan mulai dari level SD, SLTP, SLTA bahkan pendidikan tinggi harus menjadikan Pendidikan Agama Islam sebagai bagian dari kurikulum wajib (Misnan, 2018), (Rojii et al., 2020), (Zulfarno et al., 2019). PAI sebagai bagian dari kurikulum pada setiap level pendidikan sampai saat ini masih dihadapkan terhadap berbagai problem baik yang terkait dengan metode (Hakim \& Ritonga, 2018), (Aprianto et al., 2020), manajemen (Hakim et al., 2020), materi pembelajaran (Ritonga, 2017), (Ritonga et al., 2020), media pembelajaran (Susanti et al., 2020), problem yang terkait dengan kompetensi guru (Tisnelly et al., 2020) dan lain sebagainya.

Selain itu, beberapa temuan penelitian membuktikan bahwa motivasi yang dimiliki oleh anak didik memiliki pengaruh yang positif terhadap hasil pembelajaran, sebagaimana temuan Sulisttiyarni dan Sukardi yang membuktikan bahwa hasil pembelajaran matematika salah satunya dipengaruhi oleh motivasi peserta didik (Sulistiyarini \& Sukardi, 2016). Temuan lainnya ialah hasil penelitian Asvio dan kawan-kawan yang menegaskan bahwa selain lingkungan belajar motivasi memberikan dampak yang baik terhadap pembelajaran pendidikan agama Islam (Asvio et al., 2017), Penelitian Taurina juga dapat dilihat sebagai acuan dalam menarik kesimpulan bahwa motivasi siswa sangat besar pengaruhnya terhadap hasil belajar (Taurina, 2015).

Pembelajaran juga tidak bisa dipisahkan dari bagaimana perhatian peserta didik terhadap pembelajaran serta segala apa yang mesti mereka selesaikan dalam pembelajaran. Sesuai dengan kesimpulan Rubio yang mengaskan bahwa efektifitas pembelajaran itu salah satunya dapat dilihat dari tingkat perhatian peserta didik terhadap penyampaian materi oleh guru (Rubio, 2009). Hasil penelitian lainnya mengungkapkan bahwa perhatian siswa dalam mengikuti pembelajaran di dalam kelas memiliki peran yang tinggi dalam menentukan hasil pembelajaran (Ainley \& Luntley, 2007), (Rosegard \& Wilson, 2013).

Beranjak dari kesimpulan para peneliti tentang posisi motivasi dan peran perhatian sebagaimana yang dijelaskan di atas, peneliti tertarik untuk melakukan analisis lebih mendalam terkait dengan pengaruh dari motivasi dan perhatian peserta didik terhadap hasil belajar pendidikan agama Islam. Pendidikan Agama Islam dijadikan sebagai salah satu variable penelitian dikarenakan PAI sebagai bagian dari kurikulum di sekolah, di samping urgensi mata pelajaran ini dalam menumbuhkembangkan berbagai kebutuhan yang terkait dengan permasalahan dunia dan akhirat peserta didik (Yusuf et al., 2020).

Selain itu, dari studi pendahuluan yang peneliti lakukan terhadap hasil pembelajaran PAI di Sekolah Menengah Pertama 1 Sungai Bremas belum menunjukkan kualitas yang baik, hal itu terlihat sebagaimana di bawah ini:

Tabel 1 Rekapitulasi Nilai Semester I SMPN 1 Sungai Beremas Tahun Ajaran 2018/2019

\begin{tabular}{|l|l|c|c|c|c|}
\hline No. & \multicolumn{1}{|c|}{ Kelas } & $\begin{array}{c}\text { Jumlah } \\
\text { Siswa }\end{array}$ & KKM & $>$ KKM & $<$ KKM \\
\hline 1. & VIII 1 & 32 & 75 & 13 & 19 \\
\hline 2. & VIII 2 & 32 & 75 & 15 & 17 \\
\hline 3. & VIII 3 & 33 & 75 & 12 & 21 \\
\hline
\end{tabular}




\begin{tabular}{|l|l|c|c|c|c|}
\hline 4 & VIII 4 & 32 & 75 & 14 & 18 \\
\hline 5 & VIII 5 & 33 & 75 & 15 & 18 \\
\hline 6 & VIII 6 & 32 & 75 & 16 & 16 \\
\hline 7 & VIII 7 & 33 & 75 & 12 & 21 \\
\hline \multicolumn{2}{|l}{ Jumlah } & 227 & & 97 & 130 \\
\hline
\end{tabular}

(Sumber: Dokumen laporan Hasil Belajar Semester I 2018/2019)

Pada tabel di atas banyak di antara peserta didik yang tidak mencapai nilai KKM sebagaimana yang telah ditetapkan guru yaitu 75 untuk kelas VIII. Hal ini terlihat dari 227 total siswa, mereka yang mencapai Kriteria Ketuntasan Minimal hanya 97 siswa, sementara siswa yang belum meraih KKM terdapat sebanyak 130 orang, perolehan tersebut setara dengan $36,25 \%$ yang mencapai KKM dan $63,75 \%$ yang belum mencapai KKM. Dan ini juga terlihat pada hasil ujian semester 1 tahun ajaran 2018-2019 dari 227 peserta didik hanya 40/50\% peserta didik yang tuntas dan 40/50\% tidak tuntas. Oleh karena itu, perlu diungkapkan factor yang menjadi penyebab rendahnya hasil pembelajaran siswa pada matapelajaran PAI.

Tingkat ketuntasan nilai minimum yang rendah sebagaimana yang terlihat di SMP Negeri 1 sungai Bremas Pasaman Barat ini tentu banyak dipengaruhi oleh factor, disebabkan berbagai factor seperti media, metode, kompetensi guru dan lain-lain telah menjadi garapan oleh para peneliti lain, untuk itu dalam penelitian ini penulis akan mendeskripsikan pengaruh dari motivasi dan perhatian terhadap hasil pembelajaran PAI, dan pengaruh kedua variable X terhadap variabel Y.

\section{Landasan Teori}

Hasi pembelajaran Pendidikan Agama Islam meliputi kemampuan secara intelektual, kemampuan secara sikap dan kemampuan secara actual, maksudnya ialah bagaimana kemampuan peserta didik dalam mengetahui hal-hal yang bersifat teori dalam masalah yang berkaitan pendidikan agama Islam yang dipelajarinya, hal yang tidak kalah penting dalam pendidikan agama Islam ialah kemampuan mereka dalam hal mengamalkan ajaran Islam yang telah mereka pelajari.

Untuk mencapai tujuan pembelajaran PAI seperti yang diungkapkan oleh para ahli dipengaruhi oleh berbagai factor, teori yang perlu diungkapkan dalam kaitan penelitian ini ialah factor motivasi dan perhatian peserta didik. Factor motivasi ialah segala hal yang terkait dengan dorongan dan yang menggerakkan keinginan peserta didik untuk mengikuti pembelajaran (Altintas et al., 2020), (Albrecht \& Karabenick, 2018), (Gorges, 2019). Motivasi yang terkait dengan pembelajaran secara umum dapat digolongkan kepada dua, yakni motivasi internal dan motivasi eksternal (Loima et al., 2014), (Mirhadizadeh, 2016). Motivasi sebagai salah satu yang mempengaruhi hasil pembelajaran Pendidikan Agama Islam telah banyak dibuktikan oleh hasi penelitian para pemerhati bidang pendidikan agama Islam.

Selain motivasi, terkait dengan penelitian ini juga penting untuk diungkpakan teori yang terkait dengan perhatian peserta didik. Sejalan dengan itu perhatian peserta didik dapat dipahami sebagai suatu aktivtitas peserta didik yang melibatkan segala pancaindra dalam mengikuti kegiatan pembelajaran (Pluck \& Helen, 2011), (Bradbury, 2020), (Araya et al., 2016). Dari pengertian ini terlihat adanya daya tarik yang terdapat pada setiap diri peserta didik untuk merespon pesan-pesan yang disampaikan oleh guru pada kegiatan pembelajaran . 


\section{METODOLOGI PENELITIAN}

Untuk mengetahui pengaruh dari motivasi siswa terhadap hasil pembelajaran PAI, pengaruh perhatian terhadap hasil pembelajaran PAI serta pengaruh dari kedua-duanya terhadap hasil pembelajaran pendidikan agama Islam dalam penelitian ini digunakan pendekatan kuantitatif, pendekatan ini dipilih karena data yang ingin dianalisis berupa angka-angka.

Penelitian ini diadakan di Sekolah Menengah Pertama Negeri 1 Sungai Bremas Kabupaten Pasaman Barat, tempat ini dipilih karena melihat hasil pembelajaran Pendidikan Agama Islam yang masih belum sampai pada Kriteria Kemampuan Minimal. Waktu penelitian ialah sejak Juli-Agustus 2019. Adapun objek penelitian ini ialah kelas VIII, pemilihan level ini sebagai objek penelitian karena dipandang sebagai kelas yang lebih konsen dalam proses pembelajaran yang tidak disibukkan dengan persiapan ujian akhir nasional sebgaimana kelas IX, atau sudah akrab dengan lingkungan sekolah tidak seperti kondisi kelas VII yang baru menyesuaikan diri dengan lingkungan belajar.

Adapun sumber penelitian ini ialah seluruh kelas VIII semester ganjil 2018/2019, keseluruhan populasi dijadikan sebagai sampel penelitian. Sementara teknik pengumpulan data dilakukan dengan menyebarkan angket dan studi dokumentasi, penggunaan angket dimaksudkan untuk mendapatkan data yang terkait dengan motivasi peserta didik serta perhatian mereka terhadap pembelajaran pendidikan agama Islam. Dokumentasi dimaksudkan untuk mendapatkan data-data yang terkait dengan hasil pembelajaran PAI, untuk itu jenis dokumen yang dibutuhkan dalam penelitian ini ialah berupa laporan hasil pembelajaran yang dikhususkan pada matapelajaran PAI.

Untuk melakukan analisis terhadap data penelitian, pada penelitian ini digunakan analisis kuantitatif dengan berbantuan program SPSS, penggunaan SPSS dimaksudkan untuk mempermudah peneliti dalam mendapatkan temuan penelitian yang terhindar dari human error. Oleh karena itu dalam penelitian ini dibutuhkan uji normalitas, linieritas, multikolinieritas, dan uji hipotesis. Hipotesis yang digunakan dalam penelitian ini ialah "Motivasi dan perhatian peserta didik mempengaruhi terhadap hasil pembelajaran PAI".

\section{HASIL PENELITIAN DAN PEMBAHASAN}

Hasil dan pembahasan akan mendeskripsikan pengaruh variabel $\mathrm{X} 1$ terhadap Y, variable X2 terhadap Y serta variabel X1 dan X2 secara simultan terhadap Y guna menjawab apakah ada saling mempengaruhi di antara variabel.

\section{Pengaruh Motivasi terhadap Hasil Pembelajaran PAI di Sekolah Menengah Pertama Negeri}

TabeL 2. Hasil Analisis Regresi Variabel $\left(\mathrm{X}_{1}\right)$ dengan Variabel (Y)

\begin{tabular}{|c|c|c|c|c|c|c|}
\hline \multicolumn{2}{|c|}{ Model } & \multicolumn{2}{|c|}{$\begin{array}{c}\text { Unstandardized } \\
\text { Coefficients }\end{array}$} & $\begin{array}{c}\text { Standardized } \\
\text { Coefficients }\end{array}$ & \multirow{2}{*}{ Tig. } & \\
\cline { 2 - 5 } \multicolumn{2}{|c|}{} & B & Std. Error & Beta & & \\
\hline \multirow{2}{*}{1} & (Constant) & 77.689 & 7.745 & & 10.030 & .000 \\
\cline { 2 - 7 } & Variabel X1 & .026 & .064 & .054 & .397 & .693 \\
\hline \multicolumn{2}{|l}{ a. Dependent Variable: Hasil Belajar } & & & \\
\hline
\end{tabular}

Analisis data serta pengujian hipotesis menunjukkan data 2.709, sementara

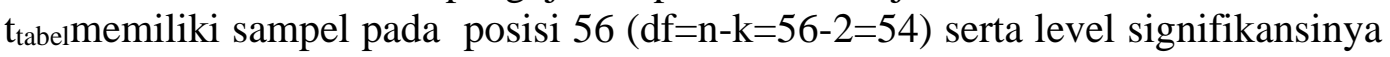


0,05 ialah 1,684. Berdasarkan hal tersebut $t_{\text {hitung }}=0,397<t_{\text {tabel }}=1,684$ dengan $\rho=$ $0,009<\alpha=0,05$ sehingga dapat dinyatakan bahwa rumusan $\mathrm{H}_{0}$ berterima dan $\mathrm{H}_{1}$ tertolak. Data ini memiliki makna bahwa terdapat pengaruh yang siginifikan dan positif antara motivasi dengan hasil pembelajaran.

Tabel 3. Analisis Koefisien Korelasi dan Koefesien Determinasi Variabel $\left(\mathrm{X}_{1}\right)$ terhadap Variabel (Y)

Model Summary ${ }^{b}$

\begin{tabular}{|c|c|c|c|c|c|c|c|c|c|}
\hline \multirow[t]{2}{*}{$\begin{array}{l}\text { Mo } \\
\text { del }\end{array}$} & \multirow[t]{2}{*}{$\mathrm{R}$} & \multirow[t]{2}{*}{$\begin{array}{c}\mathrm{R} \\
\text { Squa } \\
\text { re }\end{array}$} & \multirow[t]{2}{*}{$\begin{array}{c}\text { Adjus } \\
\text { ted R } \\
\text { Squar } \\
\text { e }\end{array}$} & \multirow[t]{2}{*}{$\begin{array}{l}\text { Std. } \\
\text { Error of } \\
\text { the } \\
\text { Estimate }\end{array}$} & \multicolumn{5}{|l|}{$\begin{array}{c}\text { Change } \\
\text { Statistic } \\
\text { s }\end{array}$} \\
\hline & & & & & $\begin{array}{c}\text { R } \\
\text { Square } \\
\text { Change }\end{array}$ & $\begin{array}{c}\mathrm{F} \\
\text { Change }\end{array}$ & df1 & df2 & $\begin{array}{c}\text { Sig. F } \\
\text { Change }\end{array}$ \\
\hline 1 & $.054^{\mathrm{a}}$ & .003 & -.016 & 2.966 & ,112 & 7,332 & 1 & 58 & ,009 \\
\hline
\end{tabular}

a. Predictors: (Constant), Motivasi Siswa

b. Dependent Variable: Hasil Pembelajaran

Sesuai analisis determinasi di atas menggunakan output model summary dapat diperoleh bahwa $R$ square sebesar 0,003 atau 0,3\% artinya kontribusi motivasi belajar sebesar $0.3 \%$ terhadap hasil belajar. Sementara sisa $99.7 \%$ dipengaruhi oleh variabel lainnya.

Table 4. Hasil Analysis of Variance (ANOVA) Variabel Motivasi Belajar ( $\left.\mathrm{X}_{1}\right)$ dengan Hasil Pembelajaran (Y)

ANOVA $^{b}$

\begin{tabular}{|c|c|c|c|c|c|c|}
\hline Model & & $\begin{array}{c}\text { Sum of } \\
\text { Squares }\end{array}$ & Df & $\begin{array}{c}\text { Mean } \\
\text { Square }\end{array}$ & $\mathrm{F}$ & Sig. \\
\hline \multirow[t]{3}{*}{1} & Regression & 1.386 & 1 & 1.386 & .157 & $.693^{\mathrm{a}}$ \\
\hline & Residual & 475.110 & 54 & 8.798 & & \\
\hline & Total & 476.496 & 55 & & & \\
\hline
\end{tabular}

a. Predictors: (Constant), Motivasi Belajar

b. Dependent Variable: Hasil Belajar

Berdasarkan analisis data dapat dilihat prediktif atau tidaknya sebuah analisis dapat menggunakan Ftest atau ANOVA atau teknik analisis of variance. Analisis ini menghasilkan Fhitung sebesar 7.332 dengan signifikansinya sebesar 0.009. F Fabel memiliki level keterpercayaan sebesar $95 \%$ dengan df pembilang $(\mathrm{df}=\mathrm{k}-1=3-1=2)$ dan $\mathrm{df}$ penyebut $(\mathrm{df}=\mathrm{n}-\mathrm{k}=56-3=53)$ yakni 3.18. Hasil pembandingan Fhitung dengan Ftabel bisa menghasilkan nilai $(7.332>3.18)$ yang menunjukkan penerimaan dari hasil regresi antara hasil belajar PAI dengan motivasi belajar.

Sesuai dengan hasil analisis yang disebutkan di atas, berbagai teori yang berkaitan dengan hal-hal yang mempengaruhi hasil pembelajaran telah mengungkapkan bahwa motivasi merupakan bagian yang penting dalam 
mendapatkan hasil belajar yang maksimal, terkadang dapat dilihat dari motivasi yang terkait dengan ajaran Islam (Sa'diyah, 2015). Kesimpulan lain mengungkapkan bahwa motivasi intrinsik dan ekstrensik sama-sama memberikan pengaruh secara langsung terhadap hasil pembelajaran (Tokan \& Imakulata, 2019). Di sisi lain Ferreira bersama kawan-kawan menyimpulkan relasi yang kuat terdapat antara motivasi dan hasil pembelajaran (Ferreira et al., 2011).

Hasil penelitian dan pernyataan para ahli sebagaimana yang diungkapkan di atas menunjukkan bahwa motivasi memberikan pengaruh yang signifikan terhadap hasil pembelajaran. Adanya keterpengaruhan itu disebabkan motivasi merupakan salah satu yang melekat pada diri peserta didik sehingga menimbulkan bagaimana cara dia mengikuti proses pembelajaran, dari proses pembelajaran tersebut kemudian akan menghasilkan kualitas proses, dan dari kualitas proses itulah kemudian muncul kualitas hasil dari pembelajaran yang diikutinya.

\section{Pengaruh Perhatian Siswa (X2) terhadap Hasil Pembelajaran PAI di Sekolah Menengah Pertama Negeri}

Table 5. Analisis Regresi Perhatian Peserta Didik $\left(\mathrm{X}_{2}\right)$ dengan Hasil Pembelajaran (Y)

\begin{tabular}{|c|c|c|c|c|c|c|}
\hline \multirow[b]{2}{*}{ Model } & & \multicolumn{2}{|c|}{$\begin{array}{l}\text { Unstandardized } \\
\text { Coefficients }\end{array}$} & \multirow{2}{*}{\begin{tabular}{|c|}
$\begin{array}{c}\text { Standardize } \\
\mathrm{d} \\
\text { Coefficient } \\
\mathrm{s}\end{array}$ \\
Beta
\end{tabular}} & \multirow[b]{2}{*}{$\mathrm{T}$} & \multirow[b]{2}{*}{ Sig. } \\
\hline & & B & Std. Error & & & \\
\hline 1 & (Constant) & 79.520 & 3.462 & & 22.968 & .000 \\
\hline & $\begin{array}{l}\text { perhatian } \\
\text { peserta didik }\end{array}$ & .014 & .040 & .049 & .360 & .720 \\
\hline
\end{tabular}

a. Dependent Variable: Hasil Pembelajaran

Berdasarkan Hasil dari tabel 5 data yang dianalisis serta pengujian hipotesis menunjukkan thitung sebesar 0.360. Sementara itu ttabel dengan posisi $56(\mathrm{df}=\mathrm{n}-\mathrm{k}=56-2=54)$ dengan tingkat signifikannya 0,05 ialah 1,684 dengan $\rho=$ $0,003<\alpha=0,05$. Perhitungan di atas bisa dipahami bahwa $\mathrm{H}_{0}$ diterima dan $\mathrm{H}_{1}$ tertolak.

Table 6. Koefisien Korelasi dan Koefesien Determinasi Variabel $\left(\mathrm{X}_{1}\right)$ terhadap Variabel (Y)

Model Summary ${ }^{\mathrm{b}}$

\begin{tabular}{|c|c|c|c|c|c|c|c|c|c|}
\hline \multirow[b]{2}{*}{$\begin{array}{l}\text { Mo } \\
\text { del }\end{array}$} & \multirow[b]{2}{*}{$\mathrm{R}$} & \multirow[b]{2}{*}{$\begin{array}{c}\mathrm{R} \\
\text { Squ } \\
\text { are }\end{array}$} & \multirow[b]{2}{*}{$\begin{array}{l}\text { Adjuste } \\
\text { d R } \\
\text { Square }\end{array}$} & \multirow{2}{*}{$\begin{array}{l}\text { Std. } \\
\text { Error of } \\
\text { the } \\
\text { Estimat } \\
\mathrm{e}\end{array}$} & \multicolumn{5}{|c|}{ Change Statistics } \\
\hline & & & & & $\begin{array}{c}\mathrm{R} \\
\text { Square } \\
\text { Change }\end{array}$ & $\begin{array}{c}\mathrm{F} \\
\text { Change }\end{array}$ & $\mathrm{df} 1$ & df2 & $\begin{array}{c}\text { Sig. F } \\
\text { Chang } \\
\text { e }\end{array}$ \\
\hline 1 & $.049^{\mathrm{a}}$ & .002 & -.016 & 2.967 & 140 & 9,462 & 1 & 58 &, 003 \\
\hline
\end{tabular}

a. Predictors: (Constant), Perhatian

b. Dependent Variable: Hasil Pembelajaran 
Data yang terdapat dalam tabel 6 analisis determinasi dengan luaran model summary menyatakan $R$ square yaitu 0,002 atau $0,2 \%$. Tabel 6 pun menunjukkan bahwa kontribusi perhatian peserta didik ialah $0.2 \%$.

Table 7. ANOVA Variabel Perhatian Peserta Didik $\left(\mathrm{X}_{2}\right)$ dengan Hasil Belajar (Y)

\begin{tabular}{|c|c|c|c|c|c|c|}
\hline \multicolumn{7}{|c|}{ ANOVA $^{b}$} \\
\hline \multicolumn{2}{|c|}{ Model } & $\begin{array}{c}\text { Sum of } \\
\text { Squares }\end{array}$ & Df & Mean Square & $\mathrm{F}$ & Sig. \\
\hline 1 & Regression & 1.142 & 1 & 1.142 & .130 & $.720^{\mathrm{a}}$ \\
\hline & Residual & 475.353 & 54 & 8.803 & & \\
\hline & Total & 476.496 & 55 & & & \\
\hline
\end{tabular}

a. Predictors: perhatian peserta didik

b. Dependent Variable: Hasil Pembelajaran

Analisis of Variance (ANOVA) digunakan untuk melihat kontribusi perhatian peserta didik bersifat prediktif ataupun tidak. Hasil tersebut

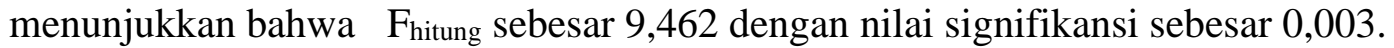
selain itu nilai $\mathrm{F}_{\text {tabel }}$ dengan level keterpercayaan $95 \%$ untuk $\mathrm{df}_{\text {pembilang }}(\mathrm{df}=\mathrm{k}$ $1=3-1=2)$ dan $\mathrm{df}_{\text {penyebut }}(\mathrm{df}=\mathrm{n}-\mathrm{k}=56-3=53)$ yaitu 3,18. Pembandingan antara $\mathrm{n}$ $F_{\text {hitung }}$ dengan $F_{\text {tabel}}$, dihasilkan $F_{\text {hitung }}>F_{\text {tabel }}$ yaitu $(9,462>3,16)$. Hal ini tentunya menandakan bahwa dapat diterima persamaan regresi antara variabel perhatian peserta didik terhadap hasil belajar PAI.

Temuan penelitian seperti yang diungkapkan di atas memiliki relevansi dengan teori-teori yang terkait dengan perhatian peserta didik, Egar mengungkapkan bahwa perhatian yang focus dari peserta didik memberikan dampak yang cukup signifikan terhadap hasil pembelajaran (Ergas, 2016), apabila konsentrasi terganggu maka hasil aktifitas tidak akan sesuai dengan tujuan yang diinginkan (Sörqvist \& Marsh, 2015), (Ohly et al., 2016). Perhatian dapat mempengaruhi hasil pembelajaran dikarenakan siswa yang mengikuti pembelajaran dengan baik akan memperlihatkan hasil yang maksimal.

Motivasi dan Perhatian Peserta Didik Secara Bersamaan Mempengaruhi Hasil Pembelajaran PAI di Sekolah Menengah Pertama Negeri

Table 8. Hasil Koefisien Korelasi dan Koefesien Determinasi $\left(\mathrm{X}_{1}\right),\left(\mathrm{X}_{2}\right)$ Secara Simultan terhadap (Y)

\begin{tabular}{|c|c|c|c|c|c|c|c|c|c|}
\hline \multirow[b]{2}{*}{ Model } & \multirow[b]{2}{*}{$\mathrm{R}$} & \multirow[b]{2}{*}{$\begin{array}{c}\mathrm{R} \\
\text { Square }\end{array}$} & \multirow[b]{2}{*}{$\begin{array}{l}\text { Adjusted } \\
\text { R Square }\end{array}$} & \multirow[b]{2}{*}{$\begin{array}{l}\text { Std. Error } \\
\text { of the } \\
\text { Estimate }\end{array}$} & \multicolumn{5}{|c|}{ Change Statistics } \\
\hline & & & & & $\begin{array}{c}\text { R } \\
\text { Squar } \\
\text { e } \\
\text { Chang } \\
\text { e }\end{array}$ & $\begin{array}{c}\mathrm{F} \\
\text { Change } \\
\end{array}$ & df1 & $\begin{array}{l}\text { df } \\
2\end{array}$ & $\begin{array}{l}\text { Sig. F } \\
\text { Chan } \\
\text { ge }\end{array}$ \\
\hline 1 & $.072^{\mathrm{a}}$ & .005 & -.032 & 2.991 & .005 & .136 & & 53 & 873 \\
\hline
\end{tabular}

a. Predictors: (Constant), perhatian siswa, Motivasi Belajar

b. Dependent Variable: Hasil Pembelajaran

a. Predictors: (Constant), Perhatian, Motivasi 
Tabel 8 menunjukkan bahwa koefiesien korelasi (R) dapat diperoleh hasil yaitu 0.072 . Hal ini menginterpretasikan adanya korelasi yang cukup kuat antara motivasi peserta didik dan perhatian peserta didik dengan hasil belajar. Semakin tinggi motivasi belajar siswa disertai tingginya perhatian siswa akan meningkatkan hasil belajar siswa. Nilai R square yang diperoleh yaitu $0.5 \%$. Hal ini dapat menunjukkan sumbangan motivasi belajar dan perhatian peserta didik ialah sebesar $0.5 \%$ sementara sisanya $99.95 \%$ yang dipengaruhi oleh variabel lainnya.

Table 9. Analisis Regresi Berganda dengan Uji F

ANOVA ${ }^{b}$

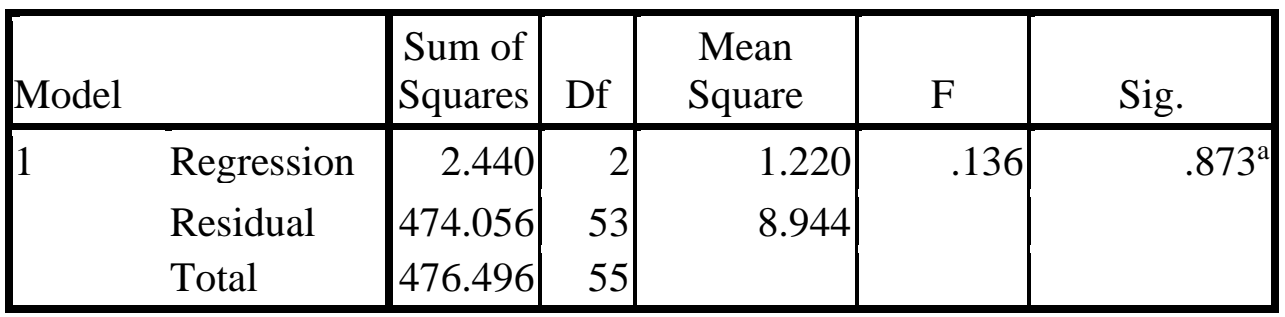

a. Predictors: (Constant), perhatian peserta didik, Motivasi

b. Dependent Variable: Hasil

Pembelajaran

Tabel di atas mengindikasikan bahwa nilai $\mathrm{F}_{\text {hitung }}$ sebesar 0.136 dalam hal ini signifikansinya ialah 0.873 . Sementara $F_{\text {tabel }}$ dengan level keterpercayaan 95 $\%$ untuk $\mathrm{df}_{\text {pembilang }}(\mathrm{df}=\mathrm{k}-1=3-1=2)$ dan $\mathrm{df}_{\text {penyebut }}(\mathrm{df}=\mathrm{n}-\mathrm{k}=56-3=53)$ yakni sebesar

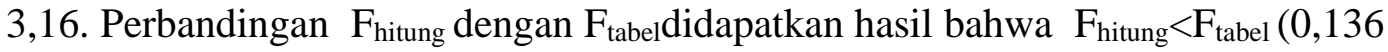
$<3,16)$. Oleh karena itu temuannya adalah $\mathrm{F}_{\text {hitung }}<\mathrm{F}_{\text {tabel }}$, oleh sebab itu $\mathrm{H}_{0}$ dapat diterima dan $\mathrm{H}_{1}$ ditolak. Perolehan data ini bermakna adanya pengaruh yang cukup signifikan serta positif antara perhatian dan motivasi terhadap hasil pembelajaran PAI di Sekolah Menengah Pertama. Berdasarkan analisis data yang dilakukan dapat disimpulkan bahwa ho ditolak dan $\mathrm{H} 1$ diterima. Pernyataan ini menunjukkan adanya pengaruh positif dan juga signifikan antara perhatian peserta didik dan motivasi belajar terhadap hasil belajar PAI.

Berdasarkan analisis data sebagaimana yang telah diuraikan dapat ditegaskan bahwa motivasi, perhatian dari siswa memberikan pengaruh yang cukup signifikan terhadap hasil pembelajaran PAI, justifikasi pada penelitian ini bisa jadi berlaku hanya untuk SMPN Sungai Bremas, namun para pendidik dan pemerhati bidang pendidikan dapat melakukan penelitian di tempat yang berbeda, justifikasi peneliti tidak bisa dipisahkan dengan teori acuan yang dijadikan pada penelitian ini, oleh karena itu hasil yang berbeda bisa jadi akan ditemukan dengan menggunakan teori yang berbeda pula. Keberhasilan dalam pembelajaran PAI sebagaimana diungkapkan oleh para ahli banyak dipengaruhi oleh berbagai factor, apa yang dihasilkan dari penelitian ini adalah bagian kecil dari yang mempengaruhi hasil pembelajaran PAI tersebut. Untuk itu, berbagai factor di luar konten atau cakupan penelitian ini menjadi garapan bagi para peneliti bidang pendidikan terutama yang mengabdikan diri pada PAI. 


\section{KESIMPULAN}

Kesimpulan dari studi ini adalah: 1) Hasil belajar PAI menduduki kategori tinggi dengan nilai rerata sebesar 80.72 yang diikiti dengan motivasi yang tinggi (120.09\%) dan perhatian yang juga tinggi (86.53\%), 2). Adanya pengaruh siginifkan dan positif pada motivasi siswa terhadap hasil pembelajaran PAI yaitu sebesar $0.3 \%$ dengan $99.7 \%$ nya disebabkan oleh variabel diluar konten penelitian. 3). Adanya pengaruh signifikan dan positif terhadap peserta didik PAI yaitu sebesar $0.2 \%$ dengan $99.8 \%$ nya disebabkan oleh factor lain, dan 4). Adanya pengaruh signifikan dan positif antara motivasi belajar serta perhatian peserta didik yang secara bersamaan terhadap hasil belajar PAI dengan hasil hasil $F_{\text {hitung }}<F_{\text {tabel }}(0,136>3,16)$ maka persentase pengaruhnya $0,005 \%$ dan $0,5 \%$ dipengaruhi oleh variabel lain. Oleh karena $\mathrm{F}_{\text {hitung }}<\mathrm{F}_{\text {tabel }}$, maka $\mathrm{H}_{0}$ diterima dan $\mathrm{H}_{1}$ ditolak. Hal ini bermakna bahwa terdapat pengaruh yang signifikan dan positif antara motivasi belajar serta perhatian siswa terhadap hasil pembelajar PAI di SMPN 1 Sungai Beremas.

\section{DAFTAR PUSTAKA}

Ainley, J., \& Luntley, Æ. M. (2007). The role of attention in expert classroom practice. J Math Teacher Educ, 10, 3-22. https://doi.org/10.1007/s10857007-9026-Z

Albrecht, J. R., \& Karabenick, S. A. (2018). Relevance for Learning and Motivation in Education. The Journal of Experimental Education, 86(1), 1-10. https://doi.org/10.1080/00220973.2017.1380593

Altintas, E., Karaca, Y., Moustafa, A., \& Haj, M. El. (2020). Effect of Best Possible Self Intervention on Situational Motivation and Commitment in Academic Context. Learning and Motivation, 69(October 2019), 1-7. https://doi.org/10.1016/j.lmot.2019.101599

Aprianto, A., Ritonga, M., Marlius, Y., \& Nusyur, R. (2020). The Influence of Using Audio- lingual Method on Students' Speaking Skill in Madrasah Diniyah Takmiliyah Awwaliyyah. Izdihar: Journal of Arabic Language Teaching, Linguistics, and Literature, 3(2), 147-160. https://doi.org/https://doi.org/10.22219/jiz.v3i2.12514

Araya, R., Farsani, D., \& Hernandez, J. (2016). How to Attract Students' Visual Attention. Adaptive and Adaptable Learning, 30-41. https://doi.org/10.1007/978-3-319-45153-4

Asvio, N., Arpinus, \& Suharmon. (2017). The Influence of Learning Motivation and Learning Environment on Undergraduate Students' Learning Achievement of Management of Islamic Education, Study Program of Iain Batusangkar. Noble International Journal of Social Science Research, 2(2), 16-31. http://napublisher.org/?ic=journals\&id=2\%0AOpen

Bradbury, N. A. (2020). Attention span during lectures: 8 seconds, 10 minutes, or more? Adv Physiol Educ, 40, 509-513. https://doi.org/10.1152/advan.00109.2016

Ergas, O. (2016). Attention Please: Positioning Attention at the Center of Curriculum and Pedagogy. Journal of Curriculum Theorizing, 31(2), 6681. 
Ferreira, M., Paula, A., \& Luís, J. (2011). Motivation and Relationship of the Student with the School as Factors Involved in the Perceived Learning. Procedia - Social and Behavioral Sciences, 29, 1707-1714. https://doi.org/10.1016/j.sbspro.2011.11.416

Gorges, J. (2019). Motivational Beliefs Specific to Business Studies Subfields: Interrelations, Antecedents, and Change in the Introductory Study Phase. IJEP International Journal of Educational Psychology, 8(2), 109-136. https://doi.org/10.17583/ijep.2019.3780

Hakim, R., \& Ritonga, M. (2018). A Study of Religion Education Method With Multicultural Insight. International Seminar on Islamic Education (ISIE 2018) Faculty of Islamic Religion, Universitas Muhammadiyah Ponorogo, July 07th, 2018, Isie 2018, 81-97.

Hakim, R., Ritonga, M., \& Susanti, W. (2020). Institute Quality Improvement Through Management Training of Accreditation Preparation in TK Aisyiyah Bustanul Athfal Padang. Advances in Social Science, Education and Humanities Research, Volume 449 Proceedings of the International Conference of Early Childhood Education (ICECE 2019), 44(Icece 2019), 55-65. https://doi.org/https://doi.org/10.2991/assehr.k.200715.012

Loima, J., Vibulphol, \& Jutarat. (2014). Internal Interest or External Performing? A Qualitative Study on Motivation and Learning of 9th Graders in Thailand Basic Education. Journal of Education and Learning, 3(3), 194203. https://doi.org/10.5539/jel.v3n3p194

Mirhadizadeh, N. (2016). Internal and External Factors in Language Learning. International Journal of Modern Language Teaching and Learning, 1(5), 188-196. www.ijmltl.com.

Misnan. (2018). Pendidikan Agama Islam: Dari Aceh untuk Indonesia. Pionir: Jurnal Pendidikan, 7(2), 1-17. https://doi.org/http://dx.doi.org/10.22373/pjp.v7i2.3866

Ohly, H., White, M. P., Wheeler, B. W., Bethel, A., Ukoumunne, O. C., Nikolaou, V., \& Garside, R. (2016). Attention Restoration Theory: A systematic review of the attention restoration potential of exposure to natural environments. Journal of Toxicology and Environmental Health, Part B, 19(7), 305-343. https://doi.org/10.1080/10937404.2016.1196155

Pluck, G., \& Helen, J. (2011). Stimulating curiosity to enhance learning. GESJ: Education Science and Psychology, 2(19), 24-31.

Ritonga, M. (2017). Desain Bahan Ajar Bahasa Arab Sains dengan Pendekatan Whole Language. Eduksi: Jurnal Pendidikan Islam, 5(1), 1-24.

Ritonga, M., Bustami, H., Saputra, R., Hakim, R., Mursal, Elhusen, S. K., \& Marlius, Y. (2020). Reformulating the arabic language teaching materials within the framework of generating new cadres of Tarjih and Tajdid Ulama. International Journal of Advanced Science and Technology, 29(7), $185-190$.

Rojii, M., Istikomah, I., \& Hidayatullah, H. (2020). Implementation of Madrasah Diniyah as Strengthening Islamic Education Curriculum at SD Khazanah Ilmu: Implementasi Madrasah Diniyah Sebagai Penguat Kurikulum Pendidikan Agama Islam Di SD Khazanah Ilmu. Proceeding of The ICECRS Conference of Management of Islamic Education Leadership in The Era of Revolution 4.0, 6, 1-15. https://jurnal.ar- 
raniry.ac.id/index.php/Pionir/article/view/3866

Rosegard, E., \& Wilson, J. (2013). Capturing Students' attention: An Empirical Study. Journal Of The Scholarship Of Teaching \& Learning, 13(5), 1-20.

Rubio, C. M. (2009). effective Teachers-Professional and Personal Skills. Revista de La Facultad de Educación de Albacete, 24, 35-46. http://www.uclm.es/ab/educacion/ensayos -

Sa'diyah, R. (2015). The Influence of Religious Motivation and Students Learning Outcomes in Islamic Religious Education Towards Students Tolerance Attitude. TARBIYA: Journal of Education in Muslim Society, 2(1), 70-82. http://journal.uinjkt.ac.id/index.php/tarbiya

Sörqvist, P., \& Marsh, J. E. (2015). How Concentration Shields Against Distraction. Aps Association for Psychological Science, 24(4), 267-272. https://doi.org/10.1177/0963721415577356

Sulistiyarini, D., \& Sukardi. (2016). The Influence of Motivation, Learning Styles, Teacher Leadership, and Teaching Intensity on Students' Learning Outcomes. Jurnal Pendidikan Teknologi Dan Kejuruan, 23(2), 136-143.

Susanti, E., Ritonga, M., \& Bambang, B. (2020). Pengaruh Penggunaan Media Powerpoint Terhadap Minat Belajar Bahasa Arab Siswa. Arabiyatuna: Jurnal Bahasa Arab, 4(1), 179-191. https://doi.org/10.29240/jba.v4i1.1406

Taurina, Z. (2015). Students' Motivation and Learning Outcomes: Significant Factors in Internal Study Quality Assurance System. International Journal for Cross-Disciplinary Subjects in Education (IJCDSE), 5(4), 2625-2630.

Tisnelly, Ritonga, M., \& Rasyid, A. (2020). The Competency of Islamic Education Teachers in Madrasah Ibtidaiyah 1 West Pasaman After Certification. Ruhama: Islamic Education Journal, 3(1), 45-56. https://jurnal.umsb.ac.id/index.php/ruhama/article/view/1940/1616

Tokan, M. K., \& Imakulata, M. M. (2019). The effect of motivation and learning behaviour on student achievement. South African Journal of Education, 39(1), 1-8. https://doi.org/10.15700/saje.v39n1a1510

Yusuf, M., Ritonga, M., \& Mursal. (2020). Implementasi Karakter Disiplin dalam Kurikulum 2013 Pada Bidang Studi PAI di SMA Islam Terpadu Darul Hikmah. Jurnal Tarbiyatuna, 11(1), 49-60. https://doi.org/https://doi.org/10.31603/tarbiyatuna.v11i1.3437 Article

Zulfarno, Mursal, \& Saputra, R. (2019). Aktualisasi Pendidikan Karakter dalam Pembelajaran Al-Islam dan Kemuhammadiyahan di SMA Muhammadiyah Kota Padang. Ruhama: Islamic Education Journal, 2(2), 117-131. 